\title{
COMPARATIVE STUDY OF HAND SEWN SINGLE LAYER ANASTOMOSIS OF DOG'S BOWEL
}

\author{
João Luiz Moreira Coutinho AZEVEDo, Octávio HYPóLITO, Otávio Cansanção AZEVEDO, \\ Otávio Monteiro BECKER Jr. and Dalmer Faria FREIRE
}

\begin{abstract}
Background - Two-layer intestinal anastomosis increases the inflammatory response while single-layer anastomosis results in a better wound healing. However the four main kinds of stitches which may be chosen in performing single layer intestinal sutures never before had been comparatively studied. Aim - To compare the four more commonly used types of single layer surgical anastomosis sutures of the digestive tract. Methods - Six mongrel dogs were operated, each one receiving two anastomosis: one at $30 \mathrm{~cm}$ from de Treitz angle - sero-submucosal technique, and the other at $60 \mathrm{~cm}$ - total technique. This placement was alternatively inverted. The four more commonly used types of single layer surgical anastomosis sutures of the digestive tract, namely: sero-submucosal stitches tied in the lumen, over the submucosa; sero-submucosal stitches tied in the exterior of the organ, over the serosa; total stitches tied in the lumen, over the mucosa; and total sutures tied in the exterior, over the serosa (Gambee's stitches) were tested. After euthanasia (7th post-operative day) macro and microscopic features were evaluated. Friedman's test was applied for morphometry and for evaluation of the peritoneal adhesions. Results - Statistical significance was demonstrated through major residual acute inflammation and proliferation in total sutures and more profuse adhesions with the sero-submucosal stitches tied in the lumen. The sero-submucosal stitches tied in the exterior over the serosa, had excellent realignment and regeneration of the layers. Conclusion - The sero-submucosal stitches tied in the exterior, over the serosa, were the best ones.
\end{abstract}

HEADINGS - Anastomosis, surgical. Sutures. Intestine, small, surgery. Dogs.

\section{INTRODUCTION}

Two-layer intestinal anastomosis increases the inflammatory response in the early stages of healing due to the ischemia of the inverted tissue, while singlelayer anastomosis results in a larger lumen with less damage to the tissue edges ${ }^{(7)}$. Clinical studies shown no significant differences between the single layer and two layer technique ${ }^{(9)}$ and experimental studies confirm these data but the time required to the performance of the single layer is shorter ${ }^{(5)}$. Among the one layer's technique there are two varieties: sub-mucosal and total which for its turn can be simple or Gambee's stitches $^{(3,4)}$. Due to the difficulty to study in clinical models the mechanisms of gastrointestinal healing after surgical anastomosis, these are better studied in animal models.

The present research was done to find out the most effective suture in a single layer: anterior sero-submucosal (AS), posterior sero-submucosal (PS), anterior total (AT) and posterior total (PT).

\section{METHODS}

Six mongrel dogs with weight from 7 to $12 \mathrm{~kg}$ were submitted to medium incision laparotomy under general anesthesia with sodium pentobarbital $30 \mathrm{mg} / \mathrm{kg}$ each one was submitted to different anastomosis (Figures $1,2,3$ and 4). One anastomosis was settled at $30 \mathrm{~cm}$ from de Treitz angle - sero-submucosal technique ${ }^{(7)}$ (AS and PS ) - and the other at $60 \mathrm{~cm}$ from the angle - total technique $^{(6)}$ (AT and PT) with single stitches at $3 \mathrm{~mm}$ interval's using blue monofilament polypropylene 4-0, 2 $\mathrm{cm}$ needle. This placement was alternatively inverted. The animals did not receive antibiotics and food was offered ad libitum. After euthanasia (7th post-operative day) macro and microscopic aspects were evaluated (Friedman's test $-P<0,01-$ to adhesions and morphometry).

\section{RESULTS}

Residual acute inflammation in the total sutures was discovered through histopathology, and a wider inflammation 


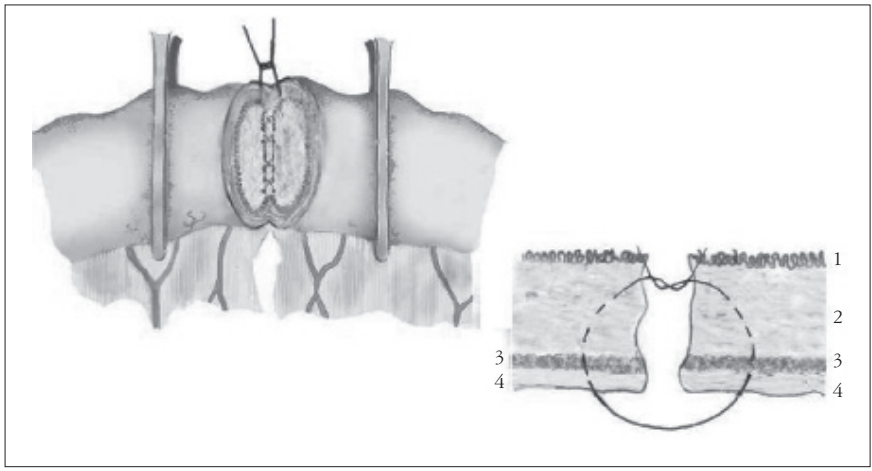

FIGURE 1. Single-layer anastomosis with posterior sero-submucosal suture of the posterior wall of the bowel. Spaeing the mucosa, the suture goes into the side of the cut surface through the submucosa (2), circular and longitudinal muscularis layers (3) and goes out to the bowel trough the serosa (4). It continues trespassing the wall of the serosa, muscularis layers and mucosa of the opposite side back into the opposite stump. The stitches are tied in the interior of the viscus, under the submucosa. The mucosa remains untouched

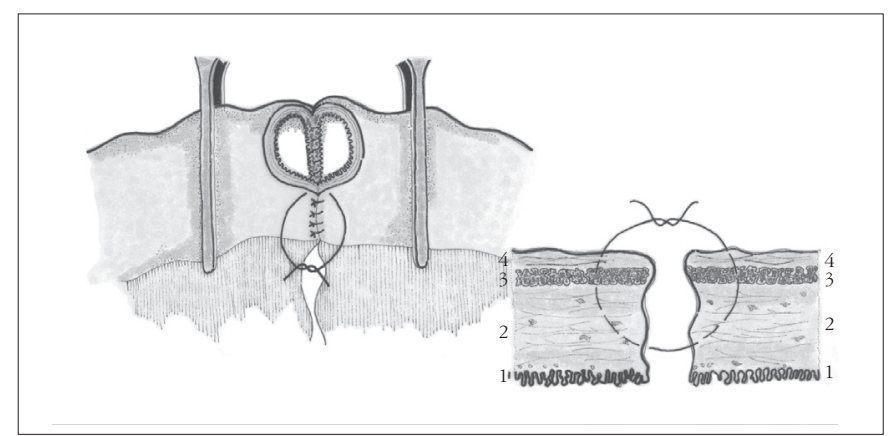

FIGURE 2. Single-layer anastomosis with anterior sero-submucosal suture of the anterior wall of the bowel. The sutures extend deeply enough to include the submucosa (2) without penetrating the mucosa. The suture goes into the wall of the serous surface, through the serosa (4), muscularis (3) and submucosa(2), out into the side of the cut surface between the mucosa (1) and submucosa (2), back into the side of the cut surface of the opposite stump between the mucosa (1) and submucosa (2), through the submucosa (2), muscularis (3) and serosa (4), out through the serous surface wall. The stitches are tied on the exterior, under the serosa

and proliferation were detected by morphometry (Figure 5). So, the adhesions were more profuse with the sero-submucosal stitches tied in the lumen - PS (Figure 6). The sero-submucosal stitches tied in the exterior, over the serosa (AS), showed minor inflammation and an excellent realignment and regeneration of the layers. At microscopy it is observed permanence of acute inflammatory response in the anterior surface (serosal tied knots) in the same way as the posterior one with edema, neutrophils and micro abscess. Langhans' granulomas immunological active kind were found around the suture stitches.

\section{DISCUSSION}

When the mucosal layer is included in surgical sutures, certain degree of ischemic necrosis always develops, even if

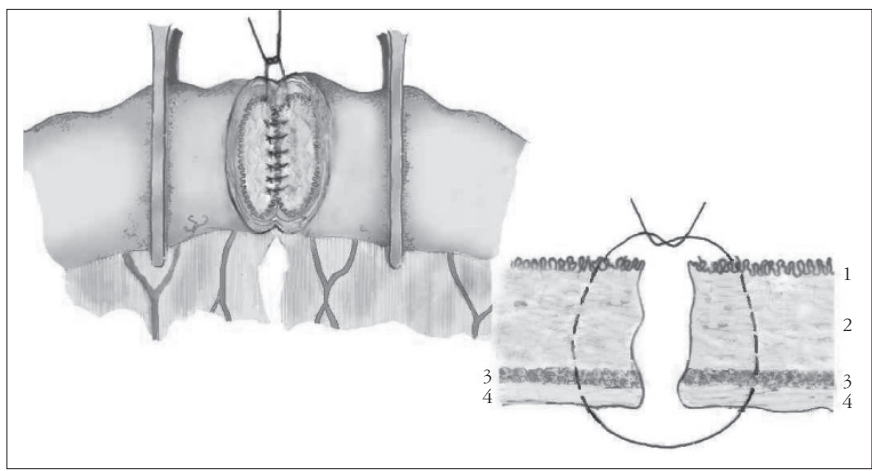

FIGURE 3. Total suture of the posterior wall. The suture goes into the mucosal surface wall, through all layers, out through the serous surface wall, back into the serous surface wall of the opposite stump, through all layers, out through the mucosal surface wall, and the stitches are tied within the viscus, under the mucosa

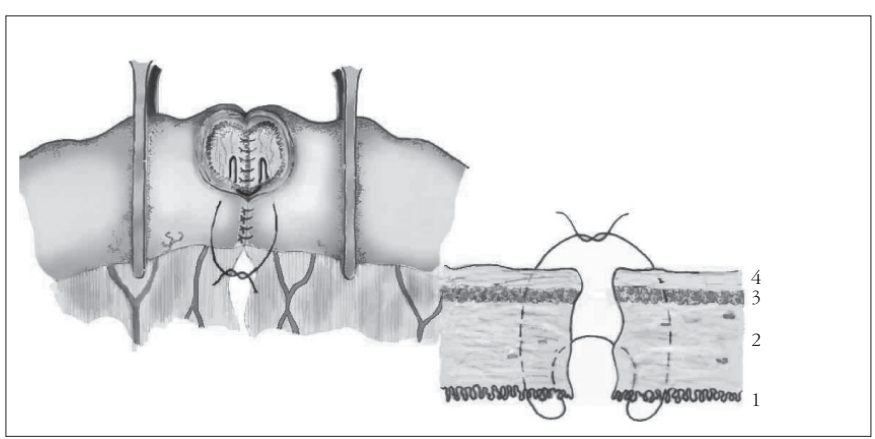

FIGURE 4. Total suture of the anterior wall of the bowel. The suture goes into the wall of the serous surface, through all layers, out through the wall of the mucosal surface, back into the mucosal surface on the same side of the incision, out into the middle of the cut surface, back into the middle of the cut surface of the opposite stump, down into gut lumen, back into the wall of the mucosal surface, through all layers, out through the wall to the serous surface and the stitches are tied under the serosal surface

the stitches are tied with the exactly needed tension in order to keep in apposition the cut edges ${ }^{(1)}$. The necrosis delays the intestinal healing, prolongs inflammation and produces excessive cellular proliferation. This phenomena was seen in the present research, with total sutures (AT and PT). Nevertheless, all this microscopic findings did not translate into dysfunction to one layer total anastomosis, nor increased the adhesions formation. So, these total sutures were judged adequate. It is quite evident in this essay that the sero-submucosal stitches tied in the exterior, over the serosa (AS), produces the best results considering the neat apposition of the layers, the fast regeneration of tissues and the prompt resolution of the inflammation phase (edema, hemorrhage, neutrophils, macrophages) with adequate proliferation of repair elements (fibroblasts, collagen fibers), and less adhesions formation. 


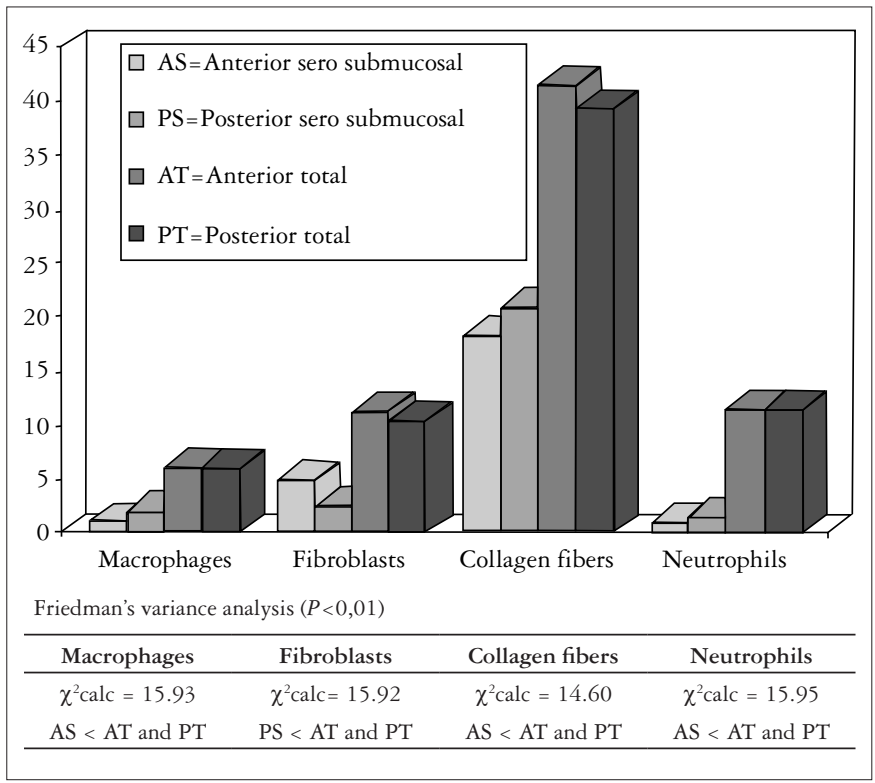

FIGURE 5. Morphometry of inflammation and proliferation (medias $=\mu$ )

On the other hand sero-submucosal sutures tied in the lumen, over the submucosal layer (PS), produces so many adhesions that it is better to avoid them at all. Probably due to the volume of the knots tied in the lumen of the bowel over the submucosal layer, what separates one cut edge of the mucosa from the other, the anastomotic seal was lost. Benjamin Travers ${ }^{(1)}$, in 1812 , wrote quite soundly: "The union of a divided bowel requires the contact of the cut extremities in their entire circumference". So it is accepted that if the mucosal edges are put in apposition one with the other in gastrointestinal anastomosis, the gap between the bowel loops is sealed and a barrier to the luminal contents leak is created. If this sealing is not complete (because of the presence of the knots tied in the lumen, over the submucosa, between the edges of the mucosa) anastomotic leaks may occur. In this circumstance, the greater omentum can play a critical role by wrapping around the suture line and adding to granulation production, thus increasing peritoneal adhesions. This type of surgical stitch (PS) must be abandoned. So, when the anatomic attachments of the operating viscera allows to complete rotation around their own transversal axis, so that the posterior half-part of the anastomosis became anterior - Swenson maneuver ${ }^{(10)}$, all the perimeter of the anastomosis must be sutured with serosubmucosal stitches tied in the exterior, over the serosa (AS). But when the organ do not permit movements of rotations

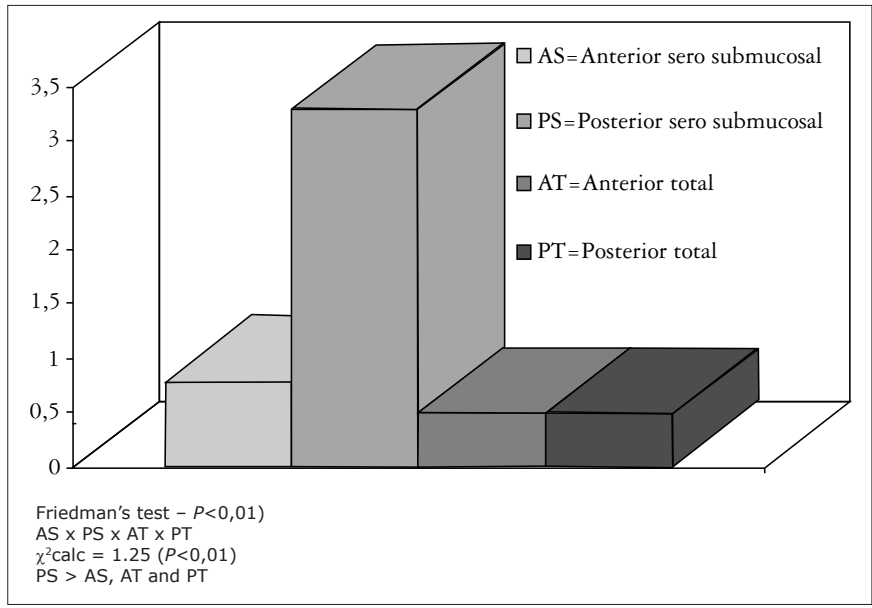

FIGURE 6. Score of the peritoneal adhesions over the suture line of the anastomosis $($ medias $=\mu)$

(stomach, rectum) or this maneuver is very difficult (esophagus operated by abdominal approach), the best solution for the suture of the posterior half-part of the anastomosis seems to be the performance of total stitches with knots tied in the lumen, over the mucosa - PT.

Again, the best construction of the single layer anastomoses is with sero-submucosal stitches tied in the exterior, over the serosa (AS), in all the perimeter of the anastomosis. Alternatively, in the impossibility of tying the knots over the serosa in the posterior half-part of the anastomosis (by virtue of technical obstacles), this must be sutured with total stitches tied in the lumen, over the mucosa PT, rather than with sero-submucosal stitches tied in the lumen, over the submucosa (PS). There are even evidences that the total discontinuous suture is better in difficult anastomosis as between the pharynx and the esophagus ${ }^{(8)}$ and furthermore it could be safely performed in a continuous mode ${ }^{(2)}$.

\section{CONCLUSION}

The sero-submucosal sutures with the knots tied in the lumen (PS) are not adequate and must be always avoided. Total stitches induce major inflammatory process. Despite of that, it is a good suture. Nevertheless, no differences exist between the two types of total sutures (AT and PT). The sero-submucosal sutures with the knots tied on the serosa (AS) produce less inflammation, less adherences, best confrontation and best layers regenerations. It must be the suture of choice every time that it may be possible to perform. 
Azevedo JLMC, Hypólito O, Azevedo OC, Becker Jr OM, Freire DF. Estudo comparativo das anastomoses manuais em plano único do intestino delgado de cães. Arq Gastroenterol. 2008;45(4):319-22.

RESUMO - Racional - As anastomoses intestinais em dois planos aumentam a resposta inflamatória tecidual, enquanto que a anastomose em plano único resulta em um lúmen maior com menos danos às bordas teciduais. Entretanto, os quatro tipos de suturas mais comumente utilizados em suturas intestinais nunca foram antes estudados comparativamente. Objetivo - Comparar os quatro tipos de sutura do tubo digestivo em plano único mais freqüentemente utilizados para anastomoses manuais do tubo digestivo. Métodos - Seis cães de raça indefinida foram operados, cada um recebendo duas anastomoses: uma a 30 cm do ângulo de Treitz - técnica sero-submucosa, e a outra a $60 \mathrm{~cm}$ - técnica total. Esta localização foi aleatoriamente invertida. Os quatro tipos de sutura em plano único mais freqüentemente utilizados para anastomoses manuais do tubo digestivo, denominados: pontos extramucoso atados no lúmen da víscera, sobre a submucosa, pontos extramucosos atados no exterior, sobre a serosa, pontos totais atados no lúmen, sobre a mucosa, e pontos totais especiais de Gambee atados no exterior sobre a serosa, foram testados. Eutanásia e necropsia parcial no $7^{\circ}$ dia pós-operatório permitiu avaliação de aspectos macro e microscópicos. O teste de Friedman's foi aplicado para a morfometria e avaliação das aderências peritoniais. Resultados - Foi demonstrada diferença estatisticamente significante para a inflamação residual aguda e maior proliferação nas suturas totais, bem como na maior ocorrência de aderências com pontos extramucosos atados no lúmen da víscera, sobre a submucosa. A sutura extramucosa com nós atados na serosa teve regeneração das bordas e alinhamento excelentes. Conclusão - A sutura extramucosa com nós atados na serosa mostrou-se a melhor.

DESCRITORES - Anastomose cirúrgica. Suturas. Intestino delgado, cirurgia. Cães.

\section{REFERENCES}

1. Azevedo JLMC, Goldenberg S, Simões MJ, Stavale JN. Estudo comparativo entre as anastomoses em plano único extramucoso e total, em cólon de coelhos. Acta Cir Bras. 1990;5:6-12.

2. Burch JM, Franciose RJ, Moore EE, Biffl WL, Offner PJ. Single-layer continuous versus two-layer interrupted intestinal anastomosis: a prospective randomized trial. Ann Surg. 2000;231:832-7.

3. Gambee LP. A single layer open intestinal anastomosis appicable to the small as well as the large intestine. Obstet Gynecol. 1951;59:1-5.

4. Gambee LP, Garnjobst W, Hardwick CE. Ten years experience with a single layer anastomosis in colon surgery. Am J Surg. 1956;92:222-7.

5. Garcia-Osogobio SM, Takahashi-Monroy T, Velasco L, Gaxiola M, Sotres-Vega A Santillan-Doherty P. Single-layer colonic anastomosis using polyglyconate (Maxon) vs. two-layer anastomosis using chromic catgut and silk. Experimental study. Rev Invest Clin. 2006;58:198-203.

6. Gorodiche J, Jourdan P. Gastrointestinal anastomosis with single plan of suture. Anastomosis digestives en un plan de suture. Sem Hop. 1951;27:3740-7.
7. Guimarães AS, Ferreira AL, Aprilli F, Carril CF. Comparison between intestinal anastomosis in 1 and 2 suture layers by study of blood vascular branching and cicatrization. Experimental work on the small intestine of the dog. AMB Rev Assoc Med Bras. 1974;20:97-101.

8. Okazaki M, Asato H, Sarukawa S, Okochi M. A revised method for pharyngoesophageal reconstruction using free jejunal transfer. Ann Plast Surg. 2005;55:643-7.

9. Shikata S, Yamagishi H, Taji Y, Shimada T, Noguchi Y. Single - versus two - layer intestinal anastomosis: a meta-analysis of randomized controlled trials. BMC Surg. 2006;6:2.

10. Swenson O. End-to-end aseptic intestinal anastomosis in infants and children. Surgery. 1954;36:192-7.

11. Travers B. An inquiry into the process of nature in repairing injuries of the intestines London: Longman, Hurst, Rees, Orme, and Brown; 1812. p.129 apud Ravitch MM, Canalis F, Weinshelbaum A, McCormick J. Studies in intestinal healing: 3. Observations on everting intestinal anastomosis. Ann Surg. 1967;166:670-80.

Recebido em 22/10/2007. Aprovado em 27/2/2008. 